\title{
RESPIRATORY ACTIVITY OF MITOCHONDRIA ISOLATED FRDOM TISSUES AND ORGANS OF THE TROPICAL FISH Oreochromis niloticus
}

\author{
SUGIZAKI, M; MALUCELLI, M.I.C.; LUCCHIARI, P.H.; CRIVELLARO, O.; BACILA, M.
}

Departamento de Medicina, Centro de Ciências Biológicas e da Saúde, Pontifícia Universidade Católica do Paraná - PUCPR. Programa Antártico Brasileiro.

A number of research work has been carried out by our group on the biochemical and physiological behavior of Antarctic organisms, particularly on the biological mechanisms of adaptation to extreme temperatures studied at molecular level. In this regard, the development of techniques for mitochondria isolation from organs and tissues of Antarctic organisms as well as the building up of special instruments for the polarographic determination of respiration and oxydative phosphorylation by the assay of oxygen uptake by means of an oxygen electrode (LUCCHIARI et al., 1998), were fundamental for the understanding of the mechanisms of biological adaptation of those animals. A comparative study is being carried out now, by our group, on the biochemical and physiological behavior of fish adapted to the tropical and subtropical regions. In the present case a research is under way on the respiratory activity of isolated mitochondria from encephalon, heart muscle and retina of the tropical fish tilapia (Oreochromis niloticus) in order to compare with the respiratory activity displayed by mitochondria from Antarctic fish. Tissues were homogenized in a Potter-Ehlvejhen homogenizer, with medium containing manitol $0.25 \mathrm{M}$, sucrose $0.075 \mathrm{M}$, EDTA, $0.001 \mathrm{M}$, TRIS, $0.001 \mathrm{M}$, phosphate buffer, $0.001 \mathrm{M}, \mathrm{pH} 7.4$. The homogenate was then spun down 10 minutes at $3,600 \mathrm{rpm}$ and the supernatant spun down again 10 minutes at $10,000 \mathrm{rpm}$ in a Beckmann refrigerated centrifuge. The pellet of mitochondria was then suspended in 1 to $2 \mathrm{ml}$ of the reaction medium and experiments on the effect of temperature and different substrates on the respiratory activity of such preparations carried out by polarography with oxygen electrode (SUGIZAKI et al., 1997, BACILA et al., 1989).

Key Words: fish, mitochondria, respiratory activity. 